\title{
After portal branch ligation in the rat, cellular proliferation in associated with selective induction of c-Ha-ras, p53, cyclin E, and Cdk2
}

\author{
P Stärkel, L Lambotte, C Sempoux, C De Saeger, A Saliez, D Maiter, Y Horsmans
}

\begin{abstract}
Background-In liver regeneration after portal branch ligation we previously showed that early cellular changes are observed in both the proliferating and atrophying liver lobes. They are therefore not indicative of future proliferative response. In this study we attempted to define precisely, in the same model, the time at which the cellular processes diverge between the lobes by measuring various parameters associated with cellular proliferation. We also investigated the possible role of inhibitors of cell proliferation in the absence of progression towards the $\mathbf{S}$ phase in the atrophying lobes.
\end{abstract}

Aims-Expression of p53, c-Ha-ras, cyclin $E$, cyclin dependent kinase (Cdk2), transforming growth factor (TGF)- $\beta$, and interleukin (IL)-1 $\alpha$ and IL-1 $\beta$ were assessed in relation to their potential role in proliferating and atrophying cellular phenomenons.

Methods-Immunohistochemistry, northern blotting, western blotting, and reverse transcription-polymerase chain reaction were performed, mainly at time points corresponding to mid-G1/S phase progression (8-24 hours after surgery).

Results-The common and thus most likely non-specific response was still evident 5-8 hours after surgery and included an increase in IL-1 mRNA as well as p53 and cyclin E proteins. From 12 hours onwards, p53, c-Ha-ras, cyclin E, and Cdk2 were selectively induced in proliferating lobes whereas IL-1 $\beta$ was predominantly activated in atrophying lobes. No changes in TGF- $\beta$ or IL-1 $\alpha$ expression were observed at the same time points in any of the liver lobes.

Conclusions-The initial response to portal branch ligation and thus probably to partial hepatectomy seems to be nonspecific for at least eight hours. Thereafter, p53, c-Ha-ras, cyclin E, and Cdk2 seem to drive cellular proliferation while IL-1 $\beta$ is associated with cellular atrophy. In contrast, TGF- $\beta$ and IL- $1 \alpha$ do not seem to play a role in determining the commitment of cells towards atrophy or proliferation.

(Gut 2001;49:119-130)

Keywords: portal branch ligation; liver regeneration; delayed early proto-oncogenes; cytokines; cyclin dependent kinase; rat
Partial hepatectomy (PH) induces many changes during the hours preceding DNA synthesis and cellular proliferation, including activation of proto-oncogenes, transcription factors, cytokines, and growth factors (for review see Fausto and Mead, ${ }^{1}$ Taub, ${ }^{2}$ Simpson and colleagues, ${ }^{3}$ Fausto and colleagues, ${ }^{4}$ and Michalopoulos and DeFrances $\left.{ }^{5}\right)$. However, it is not clear if all of these changes result from reduction in liver mass, and cause or are required for the proliferating phase. To clarify the role of these various changes, we have previously used different experimental modelsnamely, temporary partial hepatectomy and portal branch ligation (PBL) ${ }^{67}$ We have shown that early changes, including induction of immediate early proto-oncogenes and interleukin (IL)-6, as well as activation of nuclear factor $\kappa \mathrm{B}$ and Stat3, are observed in both the proliferating and atrophying lobes. ${ }^{7}$ Therefore, they are not indicative of the future proliferative response and are most likely produced in response to surgical stress. We have also shown that this initial response is independent of the reduction in liver mass. ${ }^{8}$

The PBL model also offers an unique opportunity to study the relationship of the changes observed at a later time after $\mathrm{PH}$ with stimulation or inhibition of liver growth. It was therefore intriguing to examine cellular expression of potential growth inhibitors and promoters from the mid-G1 to the G1/S phase in the regenerating and atrophying parts of the liver.

In liver regeneration, passage from $\mathrm{G} 0$ to $\mathrm{G} 1$ has been defined in hepatocytes by sequential activation of proto-oncogenes, including c-Haras and p53 expression in mid-late G1 phase. ${ }^{9}$ The p53 gene plays a critical role in mediating G1 cell cycle arrest after DNA damage and loss of p53 function can result in loss of the G1 checkpoint arrest. ${ }^{10}$ However, there is some variability in induction of p53 regulated responses and it is important to consider the tissue when evaluating the role of p53 in suppressing cell growth. ${ }^{10}$ Important elements controlling progression of cells through the cell cycle are cyclins and cyclin dependent kinases (Cdks). ${ }^{11}$ These form active kinase complexes during critical periods of the cell cycle (checkpoints) allowing transition from one stage of

Abbreviations used in this paper: IL, interleukin; PBL, portal branch ligation; PH, partial hepatectomy; RT-PCR, reverse transcription-polymerase chain reaction; TBS, Tris buffered saline; TGF, transforming growth factor; TNF, tumour necrosis factor; Cdk, cyclin dependent kinase; dTT, dithiothreitol; SDS-PAGE, sodium dodecyl sulphate-polyacrylamide gel electrophoresis. 
the cell cycle to the next. Cyclin $\mathrm{E}$ is required to catalyse the G1/S transition in normal cells ${ }^{12} 13$ as well as Cdk2 activity to stimulate cell proliferation. ${ }^{14} \mathrm{Cdk} 2$ preferentially assembles with cyclin $\mathrm{E}^{11}$ and cyclin $\mathrm{E} / \mathrm{Cdk} 2$ complexes become active during the late G1 phase contributing to the irreversible commitment of cells to enter the $S$ phase. ${ }^{14}$

Hepatocyte growth seems to be modulated by several mechanisms which may result in increased effects of hepatocyte growth promoters such as tumour necrosis factor $\alpha(\mathrm{TNF}-\alpha)$, or in a reduced effect of hepatocyte growth inhibitors, as suggested by studies with Kupffer cell depleted rats. ${ }^{15}{ }^{16}$ Transforming growth factor (TGF)- $\beta$ was shown to act as a growth inhibitor in vitro and in vivo involving paracrine and probably also autocrine mechanisms. ${ }^{17} 18$ IL-1, which shows biphasic upregulation after partial hepatectomy, was recently proposed as a potential downregulator of hepatocyte proliferation. ${ }^{19}$ However, the exact role of these molecules in counterbalancing the stimulatory effects of mitogens in liver regeneration remains unclear.

In this study, we examined the role of $\mathrm{p} 53$, TGF- $\beta$, and IL-1, three potential negative growth regulators, as well as the role of the putative cell cycle promoters c-Ha-ras, cyclin $\mathrm{E}$, and $\mathrm{Cdk} 2$, in relation to cellular atrophy and proliferation using the PBL model.

\section{Materials and methods}

ANIMALS

Male Wistar rats (220-270 g body weight) were obtained from the Rat Breeding Facilities of the Catholic University of Louvain Medical School, Brussels, Belgium. All animals were kept in a temperature and humidity controlled environment in a 12 hour light-dark cycle. At all times they were allowed free access to water and standard food pellet diet (Usine d'Alimentation Rationelle, Villemoisson-surOrges, France). The animals were handled according to the guidelines established by the Catholic University of Louvain.

SURGICAL PROCEDURES AND EXPERIMENTAL DESIGN

All operations were carried out under light ether anaesthesia at room air between 9.00 am and 12.00 am using a clean but not sterile technique. In PBL of $70 \%$ liver mass, a median laparotomy was performed and the branch of the portal vein feeding the anterior and lateral lobes was carefully dissected under an operating microscope and completely ligated with a 7-0 suture. Care was taken not to injure the hepatic artery or bile duct and to avoid haemorrhage. In controls ( 0 hours), livers were removed without any prior surgical procedure. Postoperatively, animals had free access to water and food. Rats were sacrificed by exsanguination after puncture of the abdominal aorta and transection of the inferior vena cava in the thoracic cavity at one, two, five, eight, 12, 16,24 , and 30 hours after PBL. The livers were removed, the ligated and non-ligated lobes were rapidly weighted, snap frozen in liquid nitrogen, and stored at $-80^{\circ} \mathrm{C}$. Three rats were killed at each of the indicated time points in all control groups as well as in the protooncogene, IL-1, cyclin E, and Cdk2 PBL groups. Six rats per indicated time points were used for the TGF- $\beta 1$, TGF- $\beta 2$, and TGF- $\beta 3$ experiments. The following time schedule for PBL was chosen for the different experiments: IL-1: one, two, five, eight, 12 , and 24 hours; TGF- $\beta$ : eight, 12 , and 24 hours; delayed early proto-oncogenes: 12 , and 24 hours; cyclin $\mathrm{E}$ and Cdk2: one, two, five, eight, 12, 16, and 24 hours.

PREPARATION OF HOMOGENATES, AND NUCLEAR AND CYTOPLASMIC EXTRACTS

Homogenates were obtained by homogenising whole liver tissue from the ligated and non-ligated lobes with an Ultra-turrax T25 device (IKA Labortechnik, Staufen, Germany) in a buffer containing $250 \mathrm{mM}$ sucrose, $50 \mathrm{mM}$ Tris $\mathrm{HCl}, \mathrm{pH} 7.4,5 \mathrm{mM} \mathrm{MgSO}_{4}, 1 \mathrm{mM}$ PMSF, and $2 \mu \mathrm{g} / \mathrm{ml}$ of aprotinin and leupeptin at $4^{\circ} \mathrm{C}$. Homogenates were filtered and stored at $-80^{\circ} \mathrm{C}$. Nuclear and cytoplasmic extracts were prepared separately from the anterior (ligated) and posterior (non-ligated) lobes, as described by Hattori et al with slight modifications. ${ }^{20}$ All solutions, tubes, and centrifuges were maintained at $4^{\circ} \mathrm{C}$. All buffers were supplemented with protease and phosphatase inhibitors as follows: $2 \mu \mathrm{g} / \mathrm{ml}$ each of antipain, aprotinin, bestatin, and leupeptin, $0.5 \mathrm{mM}$ $\mathrm{NaF}$, and $1 \mathrm{mM} \mathrm{Na} \mathrm{VO}_{4}$ (all protease and phosphatase inhibitors were purchased from Sigma Chemical Co., Bornem, Belgium). The nuclear extracts were resuspended in the nuclear extract dialysis buffer (25 $\mathrm{mM}$ HEPES, $40 \mathrm{mM} \mathrm{KCl}, 0.1 \mathrm{mM}$ EDTA, $1 \mathrm{mM}$ dithiothreitol (dTT), $0.5 \mathrm{mM}$ PMSF, $0.5 \mathrm{mM}$ $\mathrm{NaF}$, and $1 \mathrm{mM} \mathrm{Na} \mathrm{VO}_{4}$ ) and dialysed for four hours against $250 \mathrm{ml}$ of nuclear extract dialysis buffer with one change of dialysis solution. After dialysis, the extracts were centrifuged at $14000 \mathrm{rpm}$ for five minutes at $4^{\circ} \mathrm{C}$ in a microcentrifuge (Sorvall RMC 14; DuPont, Newtown, USA) to remove insoluble material, frozen in aliquots in liquid nitrogen, and stored at $-80^{\circ} \mathrm{C}$ until use.

After pelleting of the nuclei, the supernatants were carefully aspirated and diluted with one volume of a buffer containing $10 \%$ glycerol, 25 mM HEPES, $40 \mathrm{mM} \mathrm{KCl,} 0.1 \mathrm{mM}$ EDTA, 1 $\mathrm{mM}$ dTT, $0.5 \mathrm{mM}$ PMSF, protease, and phosphatase inhibitors. This crude cytoplasmic extract was transferred to $28 \mathrm{ml}$ ultracentrifuge tubes and spun at $24000 \mathrm{rpm}$ for two hours at $4^{\circ} \mathrm{C}$ in a SW28 ultracentrifuge rotor. The resultant supernatant was aspirated, frozen in aliquots in liquid nitrogen, and stored at $-80^{\circ} \mathrm{C}$ until use as a cytoplasmic extract. Protein contents were determined using a BCA protein assay with serum albumin as a standard (Pierce Chemical, Rockford, Illinois, USA).

\section{RNA ISOLATION}

Total RNA was prepared from frozen liver tissue using the guanidine thiocyanate and cesium chloride method. ${ }^{21}$ 
NORTHERN BLOTTING

RNA $(20 \mu \mathrm{g})$ was resolved on $1 \%$ agarose gels containing $1 \%$ formaldehyde and transferred to Hybond-N membranes (Amersham, Little Chalfont, UK). cDNA probes were ${ }^{32} \mathrm{P}$ labelled by the method of "random priming" using a Megaprime DNA labelling system (Amersham). Oligonucleotide probes were ${ }^{32} \mathrm{P}$ end labelled using a $\mathrm{T}_{4}$ polynucleotide kinase (Amersham). After ultraviolet fixation, filters were hybridised with the ${ }^{32} \mathrm{P}$ labelled oligonucleotide or cDNA probes. ${ }^{22}$ The blots were exposed to a Hyperfilm MP (Amersham) for four hours to seven days. Densitometry using a Ultroscan XL device (Pharmacia LKB, Uppsala, Sweden) was performed. The results are expressed in arbitrary densitometric units adjusted for the respective $28 \mathrm{~S}$ ribosomal signal. The p53 cDNAs were kindly provided by $\mathrm{T}$ Soussi (Inserm U301, Paris, France). ${ }^{23}$ The c-Ha-ras cDNAs were purchased from Oncor (Gaitesburg, Maryland, USA). The 28S rRNA oligonucleotide was obtained from Oncogene Sciences (Uniondale, New York, USA).

REVERSE TRANSCRIPTION-POLYMERASE CHAIN REACTION (RT-PCR)

Total liver RNA $(40 \mu \mathrm{g})$ was treated with $10 \mathrm{U}$ of Rnasin (Promega) and $1 \mathrm{U}$ of DNASE (Promega) for 15 minutes at $37^{\circ} \mathrm{C}$ in an incubation buffer (Tris $\mathrm{HCl} 10 \mathrm{mM}, \mathrm{NaCl} 50 \mathrm{mM}$, $\mathrm{MgCl}_{2} 25 \mathrm{mM}$ ) to avoid DNA contamination during PCR. The absence of genomic DNA contamination was assured by submitting samples, where reverse transcriptase had been omitted from the reaction, to PCR amplification. After incubation, the purified RNA was extracted using phenol-chloroform-isoamyl alcohol (25:24:1) (Sigma) and chloroform (Sigma), and precipitated by adding sodium acetate $3 \mathrm{M}$ and $100 \%$ ethanol. Purified RNA $(5 \mu \mathrm{g})$ was preincubated with random hexamer and water for 10 minutes at $70^{\circ} \mathrm{C}$. Moloney murine leukaemia virus reverse transcriptase 400 U (Gibco BRL, Merelbeke, Belgium) was added, together with dTT and deoxynucleoside triphosphate, and the reaction was continued for a further 60 minutes at $37^{\circ} \mathrm{C}$. The RT products were amplified in a two step PCR using Taq DNA polymerase (Boehringer Mannheim, Brussels, Belgium) and specific cDNA primers under reaction conditions listed in table 1. Ribosomal protein L19 (RPL19) RNA was co-amplified as an internal standard.
The first PCR step of five, five, and three cycles was performed using only the specific primers for cyclin $\mathrm{E}$, TGF- $\beta 2$, and TGF- $\beta 3$, respectively, followed by the second PCR step of 25 cycles during which the RPL19 primers were added. The PCRs for IL- $1 \alpha$ and TGF- $\beta 1$ were first initiated with RPL19 primers for five and four cycles, respectively, followed by the second step PCR containing primers for IL-1 $\alpha$ (25 cycles) and TGF- $\beta 1$ (26 cycles). Amplification of IL- $1 \beta$ cDNA was carried out in a single step 24 cycle PCR using IL- $1 \beta$ specific primers, and the internal RPL 19 standard was amplified in a separate PCR of 30 cycles. Digoxigenin-UTP was included to allow detection of PCR products later on.

In parallel, RNA samples obtained from lipopolysaccharide treated rats (positive control for IL- $1 \alpha$, IL- $1 \beta$, TGF- $\beta 1$, TGF- $\beta 2$, and TGF- $\beta 3$ ), and cyclin E and RPL19 RNA samples were serially diluted and co-amplified in the same PCR procedure. Standard dilution curves for IL- $1 \alpha$, IL- $1 \beta$, TGF- $\beta 1$, TGF- $\beta 2$, TGF- $\beta 3$, cyclin E, and RPL19 were thus obtained. PCR products were separated by electrophoresis through an agarose gel $(1.5 \%)$ and transferred to a nylon membrane. Bands were revealed using the Boehringer Dig Luminescent (Boehringer Mannheim) detection kit following the manufacturer's instructions. The bands were subjected to densitometric analysis, and semiquantitative analysis of signal strength was obtained by comparing measured values with their standard dilution curves. IL- $1 \alpha$, IL- $1 \beta$, TGF- $\beta 1$, TGF- $\beta 2$, TGF- $\beta 3$, and cyclin $\mathrm{E}$ values were finally adjusted for the respective RPL19 values.

\section{WESTERN BLOTTING}

A total of $25-40 \mu \mathrm{g}$ (Cdk2, cyclin E), $125 \mu \mathrm{g}$ (TGF- $\beta$ ), and $300 \mu \mathrm{g}$ (IL-1 $\beta$ ) of homogenate, nuclear, or cytosolic proteins were resolved by sodium dodecyl sulphate-polyacrylamide gel electrophoresis (SDS-PAGE) and transferred to a nitrocellulose membrane (Hybond C-extra; Amersham). The blotted membrane was blocked (one hour, room temperature) in Tris buffered saline (TBS) containing 5\% membrane blocking reagent (Amersham). All of the following incubations were carried out at room temperature in TBS containing $1 \%$ membrane blocking reagent. The incubation steps were followed by five washing steps of three minutes with TBS containing $0.1 \%$

Table 1 Primers and reaction conditions used in polymerase chain reaction amplifications

\begin{tabular}{|c|c|c|c|c|}
\hline Gene & Oligonucleotide sequences & Product size (bp) & Cycles & Reaction conditions \\
\hline IL-1 $\alpha$ & $\begin{array}{l}\text { Sense: acaggtagtgagacccacct } \\
\text { Antisense: tagtgagcaaactatagggt }\end{array}$ & 389 & 30 & $94^{\circ} \mathrm{C} 5 \mathrm{~min}, 94^{\circ} \mathrm{C} 1 \mathrm{~min}, 58^{\circ} \mathrm{C} 1 \mathrm{~min}, 72^{\circ} \mathrm{C} 2 \mathrm{~min}, 72^{\circ} \mathrm{C} 10 \mathrm{~min}$ \\
\hline IL-1 $\beta$ & $\begin{array}{l}\text { Sense: gtggcagctacctatgtctt } \\
\text { Antisense: gagaggtgctgatgtaccag }\end{array}$ & 506 & 24 & $94^{\circ} \mathrm{C} 5 \mathrm{~min}, 94^{\circ} \mathrm{C} 1 \mathrm{~min}, 60^{\circ} \mathrm{C} 1 \min 30,72^{\circ} \mathrm{C} 2 \min , 72^{\circ} \mathrm{C} 10 \mathrm{~min}$ \\
\hline TGF- $\beta 1$ & $\begin{array}{l}\text { Sense: ggactctccacctgcaagac } \\
\text { Antisense: cagagctgcgcctgcagag }\end{array}$ & 392 & 30 & $94^{\circ} \mathrm{C} 5 \min , 94^{\circ} \mathrm{C} 1 \mathrm{~min}, 62^{\circ} \mathrm{C} 1 \mathrm{~min}, 72^{\circ} \mathrm{C} 2 \min , 72^{\circ} \mathrm{C} 10 \min$ \\
\hline TGF- $\beta 2$ & $\begin{array}{l}\text { Sense: ttcgcaggtatcgatggcac } \\
\text { Antisense: gcataattgctgccttcgcc }\end{array}$ & 214 & 30 & $94^{\circ} \mathrm{C} 5 \min , 94^{\circ} \mathrm{C} 1 \mathrm{~min}, 62^{\circ} \mathrm{C} 1 \min 30,72^{\circ} \mathrm{C} 2 \min , 72^{\circ} \mathrm{C} 10 \min$ \\
\hline TGF- $\beta 3$ & $\begin{array}{l}\text { Sense: ccagctccaagcgcacag } \\
\text { Antisense: gtgcgcgagtggctgttg }\end{array}$ & 164 & 28 & $94^{\circ} \mathrm{C} 5 \min , 94^{\circ} \mathrm{C} 1 \mathrm{~min}, 64^{\circ} \mathrm{C} 1 \min 30,72^{\circ} \mathrm{C} 2 \min , 72^{\circ} \mathrm{C} 10 \min$ \\
\hline Cyclin E & $\begin{array}{l}\text { Sense: ctgaccattgtgtcctggct } \\
\text { Antisense: cagcttggacttgctggaca }\end{array}$ & 385 & 30 & $94^{\circ} \mathrm{C} 5 \min , 94^{\circ} \mathrm{C} 1 \mathrm{~min}, 60^{\circ} \mathrm{C} 1 \min 30,72^{\circ} \mathrm{C} 2 \min , 72^{\circ} \mathrm{C} 10 \min$ \\
\hline RPL19 & $\begin{array}{l}\text { Sense: agtatgctcaggcttcagaa } \\
\text { Antisense:gcaggtctaagaccaaggaa }\end{array}$ & 501 & 30 & $94^{\circ} \mathrm{C} 5 \min , 94^{\circ} \mathrm{C} 1 \min , 56^{\circ} \mathrm{C} 1 \min 30,72^{\circ} \mathrm{C} 2 \min , 72^{\circ} \mathrm{C} 10 \min$ \\
\hline
\end{tabular}


Tween 20. The following primary and secondary antibodies were used: cyclin E rabbit polyclonal (Santa Cruz Biotechnology, Santa Cruz, California, USA; 1:000; one hour); Cdk2 rabbit polyclonal (Santa Cruz; 1:000; one hour); TGF- $\beta 1$, TGF- $\beta 2$, and TGF- $\beta 3$ mouse monoclonal (Genzyme, Cambridge, Massachusetts, USA; 1:3000; two hours); IL-1 $\beta$ goat polyclonal (Santa Cruz; 1:250; one hour 30 minutes); peroxidase conjugated goat antimouse and mouse antirabbit IgGs (Jackson ImmunoResearch, West Grove, Pennsylvania, USA; 1:20000; one hour); antisheep/goat biotinylated Ig (Amersham; 1:4000; 45 minutes); and a streptavidin-horseradish peroxidase conjugate (Amersham; 1:4000; 15 minutes). The antigen-antibody reaction was visualised using the Amersham chemiluminescent detection system followed by exposure of the membranes to Hyperfilm-ECL (Amersham) for 1-3 minutes. Equal protein load on membranes and complete transfer were checked by staining gels and membranes with Coomassie blue. All blots were produced in triplicate and the amount of immunoreactive nuclear protein on each membrane was quantified using a UltroScan XL device (Pharmacia LKB). The area under the curve values were adjusted for total protein load. The final result of each sample was defined as the mean of three immunoblots performed on an identical cytoplasmic extract sample.

\section{IMMUNOPRECIPITATION AND Cdk2 KINASE}

ACTIVITY

Immunoprecipitations and kinase assays were performed as described by Jaumot and colleagues $^{24}$ with slight modifications. Briefly, $500 \mu \mathrm{g}$ of cytosolic or nuclear proteins were incubated with $1 \mu \mathrm{g}$ of anti-Cdk2 antibody (Santa Cruz) for four hours at $4^{\circ} \mathrm{C}$ in a buffer containing $50 \mathrm{mM}$ Tris, $\mathrm{pH}$ 7.4, Triton X100 $0.1 \%, 5 \mathrm{mM}$ EDTA, $250 \mathrm{mM} \mathrm{NaCl}, 50 \mathrm{mM}$ $\mathrm{NaF}, 0.1 \mathrm{mM} \mathrm{Na} \mathrm{VO}_{4}, 1 \mathrm{mM}$ PMSF, and $2 \mu \mathrm{g} / \mathrm{ml}$ leupeptin, aprotinin, antipain, and bestatin. Protein A/G Plus Agarose $20 \mu \mathrm{l}$ (Santa Cruz) was then added and incubation was carried on at $4^{\circ} \mathrm{C}$ for an additional two hours. Immunoprecipitates were harvested by centrifugation at $2500 \mathrm{rpm}$ at $4^{\circ} \mathrm{C}$ for five minutes and washed four times in washing buffer A ( 50 $\mathrm{mM}$ HEPES, $150 \mathrm{mM} \mathrm{NaCl}, 1 \mathrm{mM}$ EDTA, $2.5 \mathrm{mM}$ EGTA, $1 \mathrm{mM}$ dTT, $0.1 \mathrm{mM}$ PMSF, $0.1 \mathrm{mM} \mathrm{Na} \mathrm{VO}_{4}$, and $0.1 \%$ Tween 20) and twice in washing buffer B (50 mM HEPES, 1 $\mathrm{mM}$ dTT). To determine kinase activity, Cdk2 immunoprecipitates were incubated at $30^{\circ} \mathrm{C}$ for 20 minutes in a kinase buffer $(20 \mathrm{mM}$ HEPES, $10 \mathrm{mM} \mathrm{Mg}$ acetate, and $1 \mathrm{mM}$ dTT) containing $3 \mu \mathrm{g}$ of Histone H1 (Santa Cruz), $20 \mu \mathrm{M}$ ATP, and $10 \mu \mathrm{Ci} \mathrm{ATP}{ }^{32} \mathrm{P}$ (Amersham). The reaction was terminated by adding Laemmli sample buffer followed by $12.5 \%$ SDSPAGE. The gels were dried and the phosphorylated proteins were visualised by autoradiography.
IMMUNOHISTOCHEMISTRY

Immunohistochemical staining of hepatic paraffin sections was performed as described previously with slight modifications. ${ }^{25}$ Thin slices of liver tissue were immediately fixed in phosphate buffered $4 \%$ formaldehyde for a period of 24 hours. Before immunostaining, the slides were placed in a citrate buffer $(\mathrm{pH}$ 5.7) and treated with one cycle of three minutes at $750 \mathrm{~W}$ and four cycles of 3.5 minutes at $350 \mathrm{~W}$ in a microwave oven (Whirlpool, Göteborg, Sweden) to ensure optimal retrieval of the antigens. ${ }^{26}$ The following primary antibody was used: an anti-p53 rabbit polyclonal antibody (Novocastra Laboratories, Newcastle, UK) at a dilution of 1:400 (overnight, $4^{\circ} \mathrm{C}$ ). The specificity of the staining was ensured by omitting the primary antibody from the reaction and by replacing the primary antibody by a non-relevant rabbit polyclonal antibody. The overall surface of the sections was measured and all p53 labelled nuclei were counted. The results of nuclei counts were adjusted for the section surface.

\section{STATISTICAL ANALYSIS}

Results are expressed as mean (SEM). Statistical differences between groups were tested using one way analysis of variance (ANOVA). Statistical significance was assumed for $p$ values $<0.05$.

\section{Results}

EXPRESSION OF $\mathrm{p} 53$ AND c-Ha-ras mRNA

Low p53 (fig 1A, C) and c-Ha-ras (fig 1B, C) transcript levels were found in all control animals. Following PBL, a significant increase in both transcripts was observed only in regenerating lobes from 12 hours onwards after PBL. Peak expression of p53 (150\% increase) occurred at 12 hours $(\mathrm{p}<0.01)$ followed by a decline to baseline values at 24 hours (fig 1A, C) whereas c-Ha-ras progressively increased until 24 hours $(100 \%$ increase; $p<0.001)$ (fig 1 B, C). No increase over baseline levels was noted in the anterior lobes.

IMMUNOHISTOCHEMISTRY OF p53 PROTEIN

No major histological differences between the lobes, in particular no foci of necroses, were observed until 30 hours after PBL. p53 expressing nuclei were homogeneously distributed over the whole liver and did not show preferential periportal or centrilobular distribution at any of the investigated time points (fig 2A-F).

Only a few hepatocyte nuclei expressing p53 protein were observed in the control groups (fig 2G). No elevation over baseline levels in p53 positive nuclei was present in both lobes one hour after PBL whereas a slight but significant increase in nuclear staining was found at five hours (posterior lobes $118(42) \times 10^{-2} / \mathrm{mm}^{2}$ and anterior lobes $127(22) \times 10^{-2} / \mathrm{mm}^{2}: \mathrm{p}<0.01$ $v 0$ hours). However, there was no statistically significant difference between both lobes at this time point (fig 2G). In the posterior lobes, a further elevation in p53 positive nuclei was observed at 30 hours after PBL while the 

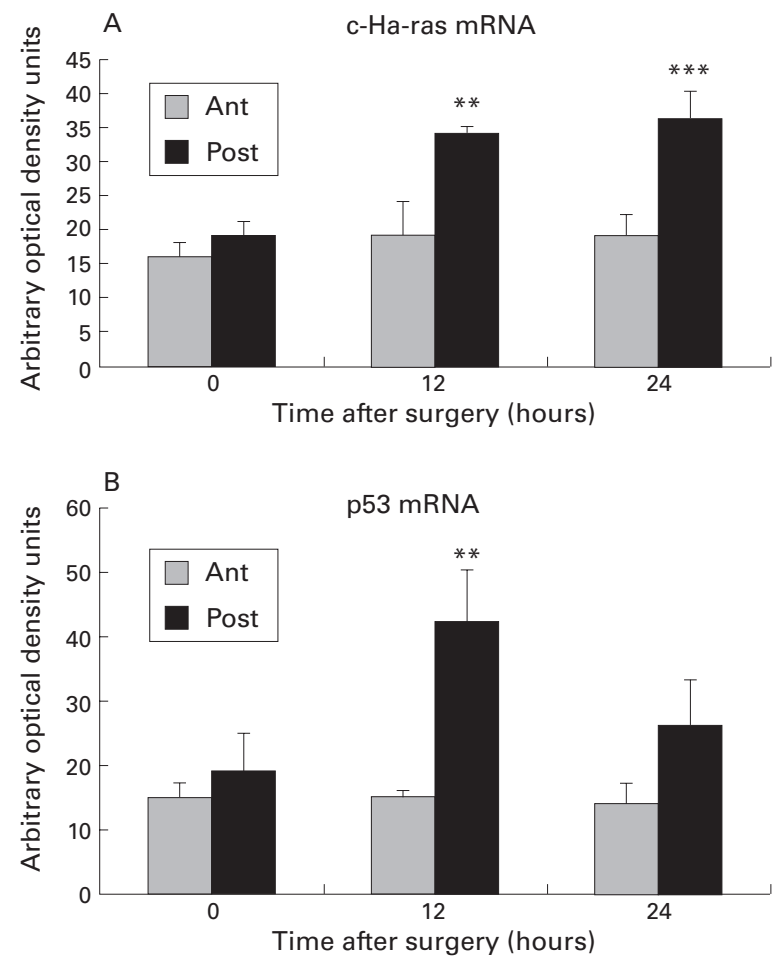

C

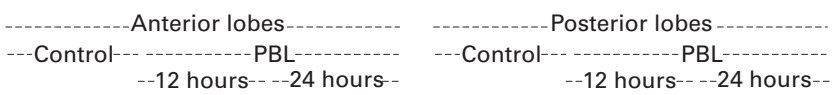
p53

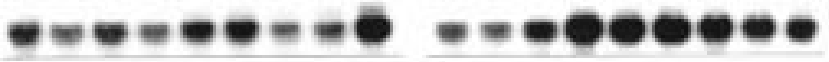

c-Ha-ras

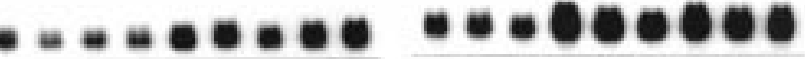

$28 \mathrm{~S}$

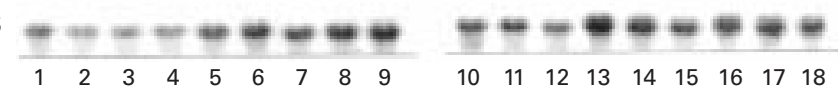

Figure 1 Northern blot analysis of p53 and c-Ha-ras $m R N A$. (A) Quantification of $c$-Ha-ras $m R N A$ by densitometric analysis of the blots. The adjusted values did not reveal any significant rise in c-Ha-ras $m R N A$ in the anterior lobes. In the posterior lobes, a significant increase in c-Ha-ras level was noticed from 12 hours after portal branch ligation $(P B L) .{ }^{\star \star} p<0.01,{ }^{\star \star *} p<0.001$. (B) Quantification of $p 53 \mathrm{mRNA}$ by densitometric analysis of the blots. After adjustment for the respective $28 S$ ribosomal signals, no elevation above baseline levels was observed in atrophying (Ant) lobes whereas $p 53 \mathrm{mRNA}$ was significantly upregulated $\left({ }^{\star *} p<0.01\right)$ in regenerating (Post) lobes at 12 hours after PBL. (C) Northern blots of $p 53, c-H a-r a s$, and $28 S m R N A$ s extracted from control animals (lanes 1-3 and 10-12) as well as from the anterior and posterior lobes of PBL animals lanes 4-9 and 13-18, respectively). Total liver $m R N A(20 \mu g)$ was separated by electrophoresis on agarose gels, hybridised with their respective ${ }^{32} \mathrm{P}$ labelled $c D N A s$, and blotted. Signals were analysed by densitometry and adjusted for their $28 S$ signals.

number of nuclei staining positive for $\mathrm{p} 53$ significantly declined in the anterior lobes (fig $2 \mathrm{G})$. At this time point, a significant difference between both lobes became obvious (anterior lobes $62(14) \times 10^{-2} / \mathrm{mm}^{2} v$ posterior lobes 347 $\left.(123) \times 10^{-2} / \mathrm{mm}^{2} ; \mathrm{p}<0.05\right)$.

EXPRESSION OF CYCLIN E

Cyclin E mRNA

Low amounts of cyclin $\mathrm{E}$ transcripts were detected in untreated animals. After PBL, no changes in cyclin mRNA expression were noticed in the atrophying lobes until 24 hours. In the regenerating lobes however mRNA levels started to rise from 12 hours onwards and a significant increase $(\mathrm{p}<0.01)$ was clearly seen at 24 hours after surgery (fig 3 )
Cyclin E protein

In the cytosol. Western blot analysis revealed two distinct bands of approximately 52 and 54 $\mathrm{kDa}$, which most likely correspond to the previously described active cyclin $\mathrm{E}$ molecules originating from alternatively spliced mRNAs. ${ }^{27}{ }^{28}$ Very low levels of cyclin E were present in the cytosol of control and sham operated animals. No increase was seen after sham operation but cyclin $\mathrm{E}$ was equally upregulated in the anterior and posterior lobes during the first five hours after PBL (fig 4A). A significant reduction in cyclin $\mathrm{E}$ protein expression occurred at 12 and 24 hours in the atrophying lobes. Nevertheless, protein levels remained above control values at these time points in the anterior lobes (fig 4B). In contrast, in the regenerating lobes, a further significant increase in overall cyclin $\mathrm{E}$ expression $(p<0.001)$ was observed from eight hours onwards after PBL which was mainly due to upregulation of faster migrating $(52 \mathrm{kDa})$ cyclin $\mathrm{E}$ band (fig 4A, B). Cyclin $\mathrm{E}$ protein expression reached a peak in the posterior lobes at 12 hours and remained at significantly higher levels in these lobes compared with the atrophying lobes until 24 hours after surgery (fig 4B). In the nuclear fraction. Cyclin $\mathrm{E}$ was only barely detectable in nuclear extracts from control and PBL animals before 12 hours after surgery. Thereafter, cyclin E was detected as two distinct bands of about 52 and $54 \mathrm{kDa}$ in the regenerating liver lobes. At 12 hours after PBL, the $52 \mathrm{kDa}$ band was predominately found whereas the $54 \mathrm{kDa}$ band was only weakly expressed. Interestingly, at 24 hours the ratio of the slow migrating $(54 \mathrm{kDa})$ to the faster migrating $(52 \mathrm{kDa})$ band changed. Strong upregulation of the first was observed whereas the latter did not increase further (fig 5).

EXPRESSION OF Cdk2

In the cytosol

Low amounts of Cdk2 protein expression were found in quiescent livers of control animals (fig 5A). As early as one hour after PBL, a similar increase in Cdk2 levels was observed in the atrophying and regenerating lobes. Thereafter, Cdk2 levels decreased steadily in both parts of the liver to reach control values at eight hours after surgery. From 12 hours onwards, a divergent evolution became obvious between both parts of the liver. Cdk2 levels remained similar to controls in the atrophying lobes whereas significant $(p<0.01)$ upregulation was noted in the regenerating lobes (fig 5B). Only in the posterior lobes were high amounts of Cdk2 continuously detected until 24 hours after PBL.

\section{In the nuclear fraction}

Low signals of Cdk2 were also detected in liver nuclear extracts prepared from untreated control animals (fig 6A). In the atrophying lobes, no increase in Cdk2 expression was seen during the whole experiment. Indeed, immunoquantification revealed levels of Cdk2 expression slightly below control values in the anterior lobes (fig 6B). In the regenerating lobes however Cdk2 levels increased progressively from 12 

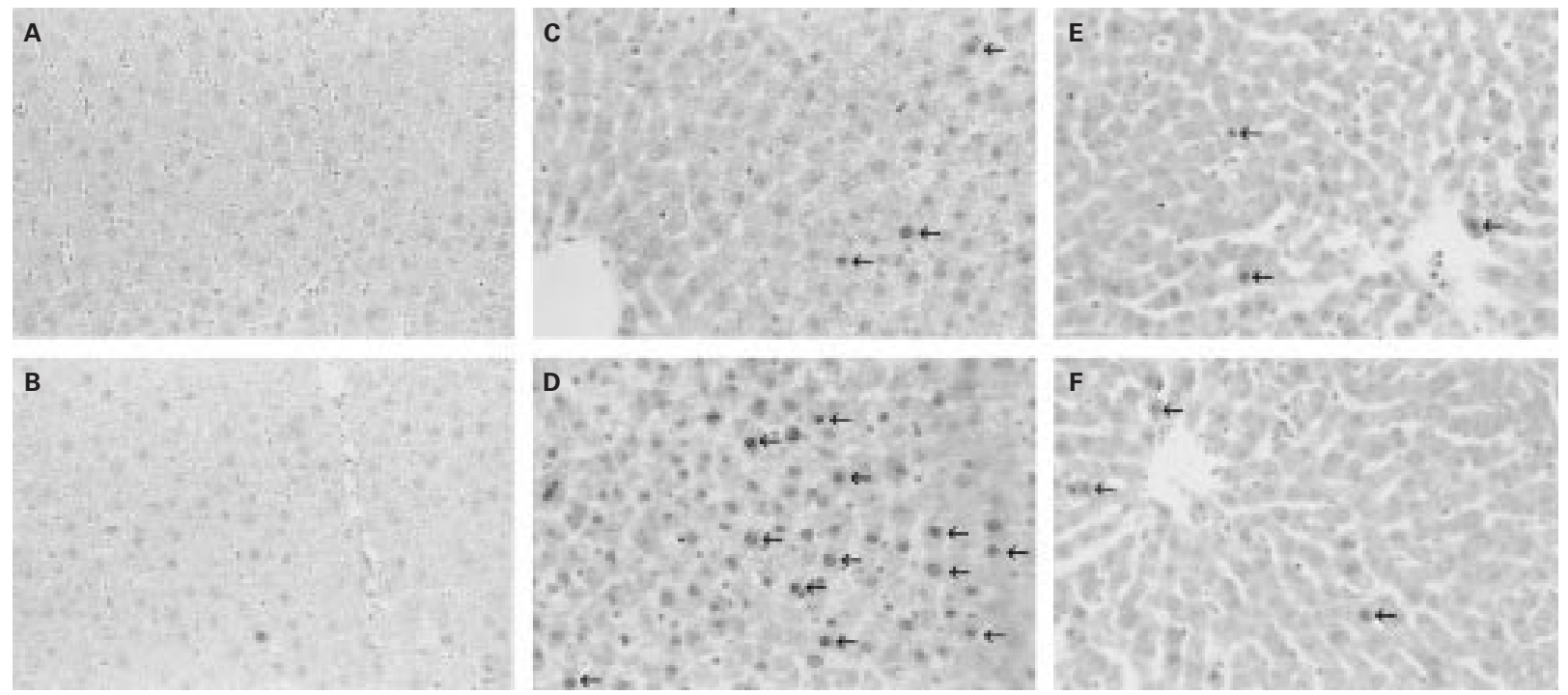

Figure 2 Immunohistochemistry of $p 53$ protein expression after portal branch ligation $(P B L) .(A-F)$ Histology and $p 53$ nuclear staining. Slides were stained immunohistochemically with a polyclonal anti-p53 antibody. No staining is observed in the anterior and posterior lobes of control animals ( $A$, $B)$. At five hours, nuclear staining (indicated by arrows) is slightly enhanced in both parts of the liver $(E, F)$. At 30 hours, no further increase in $p 53$ staining is noticed in the anterior lobes $(C)$ whereas marked upregulation in positive staining nuclei is seen in the posterior lobes (D). (G) Quantification of $p 53$ labelled nuclei. The labelled nuclei were counted in the anterior (Ant) and posterior (Post) lobes of control (O hours) and PBL animals at one, five, and 30 hours. The final result was adjusted for the surface $\left(\mathrm{mm}^{2}\right)$ of the section. A similar and significant increase in $p 53$ positive nuclei was noticed in the regenerating (Post) and atrophying (Ant) lobes at five hours after PBL (**p<0.01 and $* * * p<0.001$, respectively) whereas at 30 hours a further rise

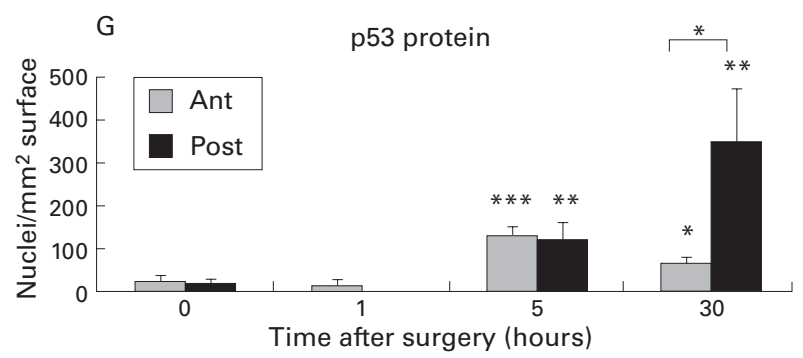
in $p 53$ positive nuclei was only shown in the regenerating lobes. At this time point a significant difference between the lobes was observed $\left({ }^{\star} p<0.05\right)$.

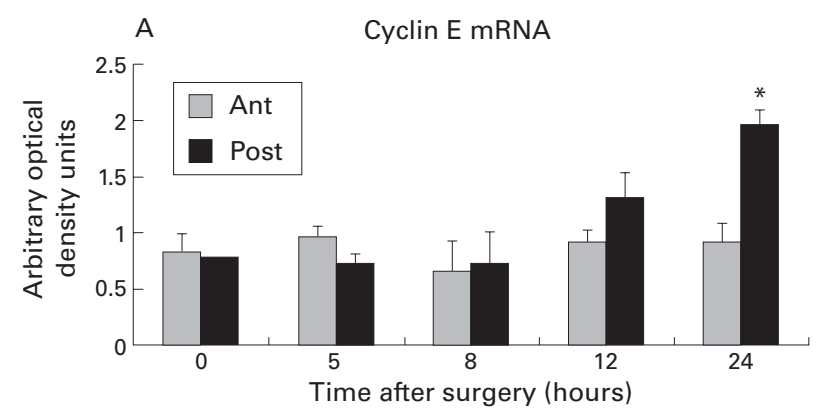

B

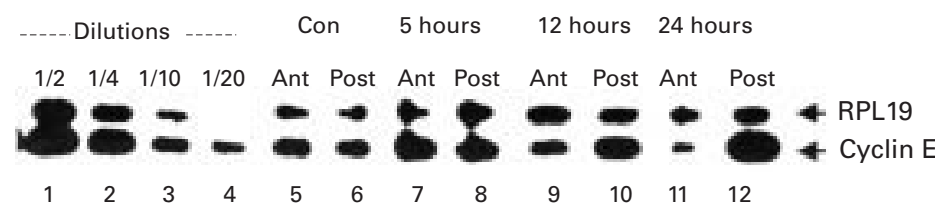

Figure 3 Expression of cyclin $E m R N A$ in the atrophying and regenerating lobes after portal branch ligation (PBL). (A) Quantification of cyclin $E m R N A$ by densitometric analysis. Total liver RNA obtained from the atrophying (Ant) and regenerating (Post) lobes was subjected to reverse transcription-polymerase chain reaction (RT-PCR), as described in materials and methods. The results were adjusted for their respective RPL19 levels and then compared with a standard dilution curve obtained by amplification of a cyclin $E m R N A$ sample in the same PCR procedure. A significant induction of cyclin $E$ $m R N A$ was only observed in the regenerating lobes at 24 hours after $P B L\left({ }^{\star} p<0.05\right)$. (B) RT-PCR of cyclin E mRNA. Representation of RT-PCR of RPL19 and cyclin E $m R N A$ in control animals (lanes 5 and 6 ) and in the atrophying (Ant) and regenerating (Post) lobes at various time points after PBL (lanes 7-12). Total liver RNA was subjected to RT-PCR as described in materials and methods. The results were adjusted for their respective RPL19 levels and compared with a standard dilution curve obtained by amplification of liver $m R N A$ from lipopolysaccharide treated rats in the same PCR procedure (lanes 1-4). hours onwards after PBL. At 24 hours, highly significant upregulation $(\mathrm{p}<0.001)$ of $\mathrm{Cdk} 2$ was observed in the nuclear fractions prepared from posterior lobes (fig $6 \mathrm{~B}$ ).

HISTONE H1 KINASE ACTIVITY

Cdk2 was immunoprecipitated and a histone H1 kinase assay was performed on immunoprecipitates harvested from cytosolic and nuclear fractions. Cdk2 kinase activity was detectable in the cytosolic fraction from either part of the liver during the 24 hour experiment without major variations over the examined time period (fig 7A). No Cdk2 associated activity was found in nuclear fractions from the atrophying lobes at any of the investigated time points. In contrast, Cdk 2 kinase activity was clearly and selectively present in the nuclear fractions obtained from the regenerating lobes at 24 hours after PBL (fig 7B). Detectable Cdk2 activity in the nucleus correlated with strong upregulation of nuclear $\mathrm{Cdk} 2$ protein and corresponded to the peak of DNA synthesis.

EXPRESSION OF TGF- $\beta$

$T G F-\beta 1, T G F-\beta 2$, and TGF- $\beta 3$ mRNAs

No significant changes in TGF- $\beta 1$, TGF- $\beta 2$, or TGF- $\beta 3$ mRNA levels were observed in both lobes during the first 24 hours after PBL (fig 8). 

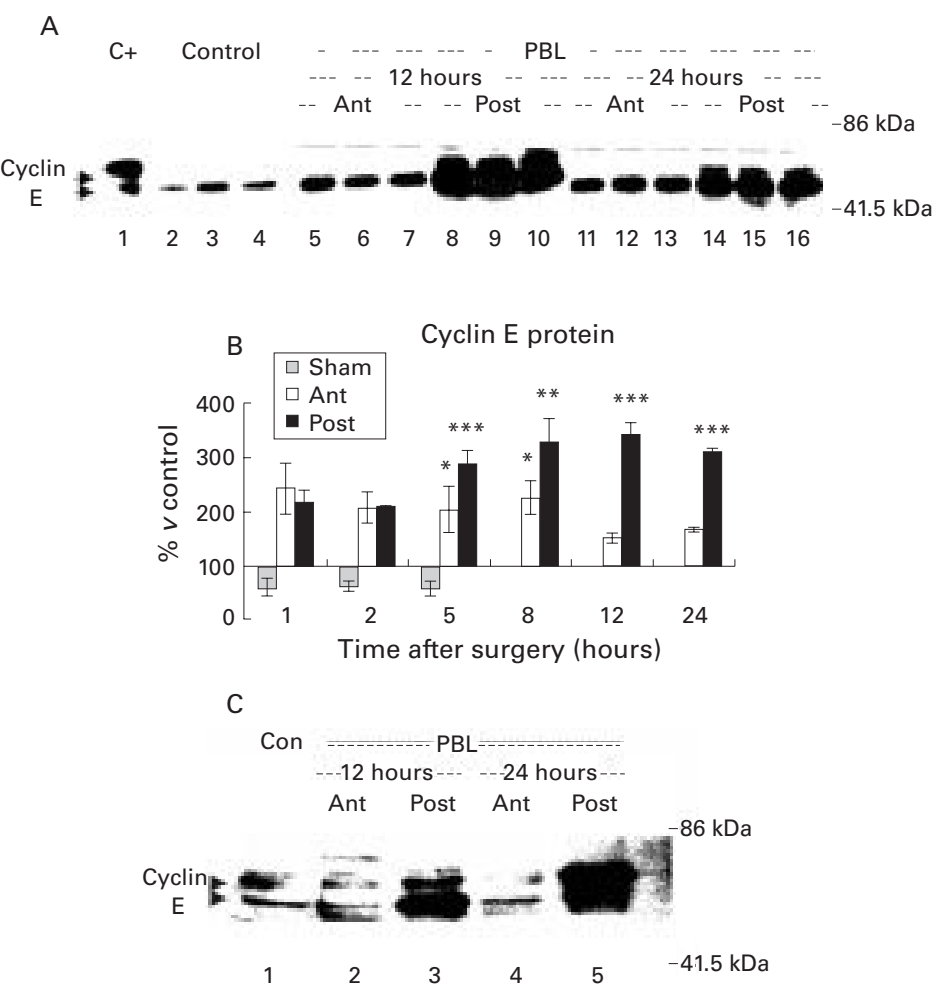

Figure 4 Western blot of cyclin E protein. (A) Cytoplasmic proteins ( $40 \mu \mathrm{g}$ ) were resolved using $8 \%$ sodium dodecyl sulphate-polyacrylamide gel electrophoresis and blotted with an anti-cyclin $E$ polyclonal antibody. Samples from control animals (O hours) and from the atrophying (Ant) and regenerating (Post) lobes of animals at various times after portal branch ligation (PBL) were analysed. The antibody recognised two bands of approximately 52 and $54 \mathrm{kDa}$ in control and PBL animals. A representative blot of three control (lanes 2-4) and three PBL cytosol extracts at 12 hours (lanes 5-10) and 24 hours (lanes 11-16) after surgery is shown. KNRK nuclear extracts were used as a positive control $(C+$, lane 1). (B) Quantification of cyclin E protein in the cytoplasm by densitometry. Cyclin $E$ protein was rapidly upregulated in both lobes within the first hours after PBL. A further significant increase was observed in the regenerating lobes between 8 and 24 hours after $P B L\left({ }^{*} p<0.01,{ }^{* \star} p<0.001\right.$, respectively). In contrast, cyclin $E$ protein expression decreased in the atrophying lobes during the same time without, however, reaching control levels. (C) Nuclear proteins $(40 \mu \mathrm{g})$ were subjected to western blot analysis. Very low amounts of cyclin $E$ protein were detected in the nuclear fraction of control livers (Con). A faint band of approximately $52 \mathrm{kDa}$ was found in nuclear fractions of both lobes at all investigated time points which increased selectively in the regenerating lobes (Post) from 12 hours onwards (lane 3). A slower migrating approximately 54 kD band, initially weakly present in both parts, was strongly upregulated in the nuclear fractions from the regenerating (Post) lobes at 24 hours (lane 5).

TGF- $\beta$ proteins

Use of an antibody recognising all three TGF- $\beta$ isoforms did not show any difference in TGF- $\beta$ expression up to 24 hours after PBL (not shown).

EXPRESSION OF IL-1

IL-1a

No significant changes in IL- $1 \alpha$ mRNA were seen, in atrophying or regenerating lobes throughout the entire experiment (not shown).

$I L-1 \beta$

$I L-1 \beta m R N A$. IL-1 $\beta$ mRNA levels increased similarly in the anterior and posterior lobes until five hours after PBL. From eight hours onwards, a difference became apparent between both lobes. In atrophying lobes, IL-1 $\beta$ decreased slightly thereafter but remained significantly higher than control levels until 24 hours after PBL (fig 9A, B). In contrast, in the regenerating lobes, IL- $1 \beta$ mRNA expression had returned to control values eight hours after PBL (fig 9A, B).

\section{A}
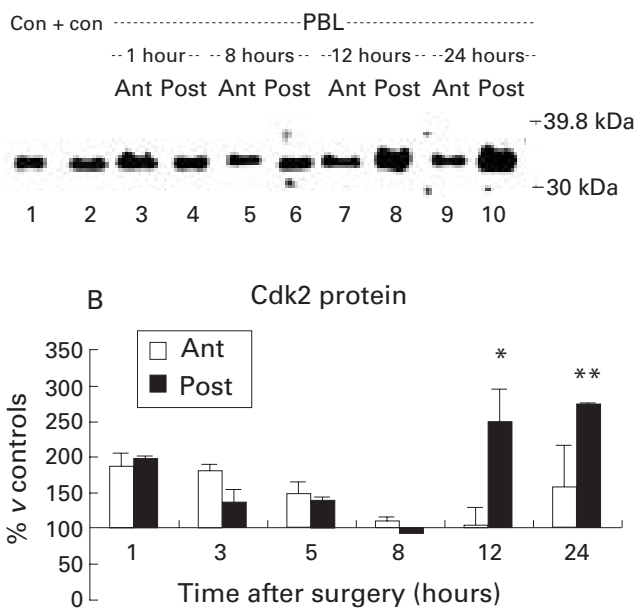

Figure 5 Western blot of cyclin dependent kinase (Cdk2) protein in the cytoplasm. (A) Cytoplasmic proteins $(30 \mu \mathrm{g})$ were resolved using $8 \%$ sodium dodecyl

sulphate-polyacrylamide gel electrophoresis and blotted with an anti-Cdk2 polyclonal antibody. Samples from control animals (0 hours) and from the atrophying (Ant) and regenerating (Post) lobes of animals at various times after portal branch ligation (PBL) were analysed. An approximately $34 \mathrm{kDa}$ band was found in control livers (Con, lane 2) and in both lobes after PBL. Increased expression was observed in the regenerating (Post) lobes mainly at 12 and 24 hours after PBL (lanes 8 and 10, respectively). KNKR nuclear extracts were used as a positive control (Con+, lane 1). (B) Quantification of Cdk2 protein in the cytoplasm by densitometry. Cdk2 was similarly increased in both lobes during the very first hours after PBL but returned to control levels at eight hours. Thereafter, Cdk2 increased again significantly $\left({ }^{\star} p<0.05 ;{ }^{* *} p<0.01\right)$ only in the regenerating (Post) lobes until 24 hours after PBL.

IL-1 $\beta$ protein. To investigate if persistent IL- $1 \beta$ mRNA expression in atrophying lobes correlated with IL-1 $\beta$ protein expression, western blot analysis of liver homogenates derived from the atrophying and regenerating lobes at eight, 12, and 24 hours after PBL was carried out. At high protein loads, an approximately $31 \mathrm{kDa}$ band was detected by the antibody raised against the $31 \mathrm{kDa}$ precursor of the IL- $1 \beta$ protein. This band was observed only in the atrophying and not in the regenerating lobes at eight, 12, and 24 hours after PBL (fig 9C). Maximal levels of IL-1 $\beta$ immunoreactive protein were reached in the atrophying lobes at approximately 12 hours after PBL.

\section{Discussion}

Portal branch ligation constitutes an ideal model to study the specificity and role of several factors in the development of liver atrophy or regeneration as both processes are concomitantly observed within the same liver. In this model of liver regeneration, opposite responses were induced eight hours or later after surgery in the anterior and posterior lobes related to cellular atrophy and cellular proliferation, respectively. Persistent expression of IL-1 $\beta$ was observed in the atrophying lobes whereas p53, c-Ha-ras, cyclin E, and Cdk2 were selectively and persistently activated in the regenerating lobes. We have previously shown that the early cellular responses in the PBL model, including activation of nucleur factor $\kappa \mathrm{B}$, Stat3, IL-6, c-fos, c-myc, and c-jun 

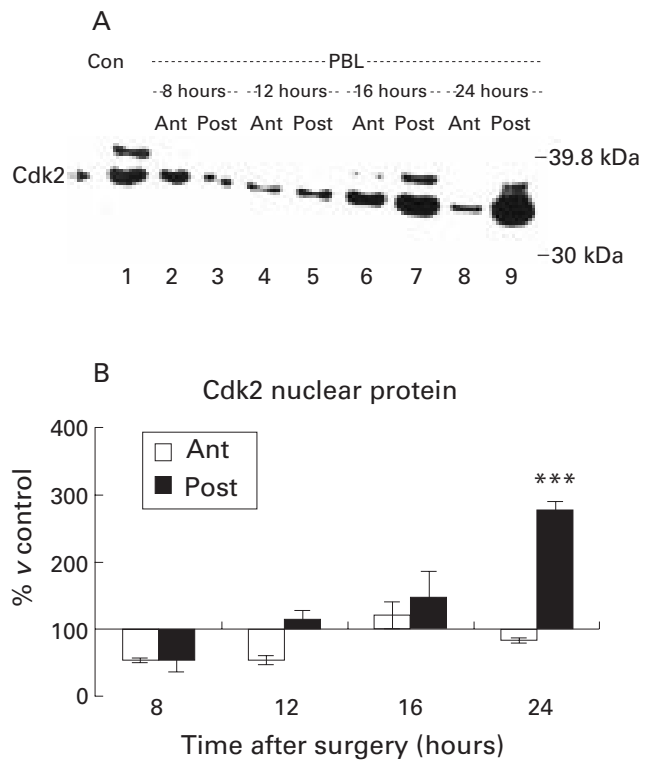

Figure 6 Western blot of cyclin dependent kinase (Cdk2) protein in the nuclear fraction. (A) Cytoplasmic proteins (30 $\mu \mathrm{g})$ were resolved using $8 \%$ sodium dodecyl sulphate-polyacrylamide gel electrophoresis and blotted with an anti-Cdk2 polyclonal antibody. Samples from control animals (Con) and from the atrophying (Ant) and regenerating (Post) lobes of animals at various times after portal branch ligation (PBL) were analysed. Low levels of Cdk2 were found in control livers (Con, lane 1) and in the atrophying (Ant) lobes after PBL. Increased expression was observed in the regenerating (Post) lobes from 16 hours onwards, reaching a peak at 24 hours after PBL (lanes 7 and 9 , respectively). (B) Quantification of Cdk2 protein in the nuclear fraction by densitometry. No significant increase in Cdk2 expression compared with control levels was seen in the atrophying (Ant) lobes after PBL. In the regenerating (Post) lobes however Cdk2 levels started to rise from 12 hours after PBL and reached a significant peak $\left({ }^{\star *} p<0.001\right)$ at 24 hours after $P B L$.

were similarly obtained in the anterior and posterior lobes. ${ }^{7}$ The present observations of similar activation of p53 protein and IL- 1 in both parts of the liver during the first 5-8 hours after PBL also favours the absence of specificity of these early events. However, the methods used in this study were semiquantitative and do not allow exclusion of an eventual, although unlikely, threshold phenomenon during the early phase. As cross talk and cooperation between proteins and transcription factors exist, we cannot formally exclude the possibility that specific interplay of these factors at early time points may influence future cell fate. At present it is difficult to investigate these mechanisms. However, and more importantly, our results provide strong evidence that the cellular response in the atrophying and regenerating lobes follows a divergent specific pathway at approximately 12 hours after PBL. The results also suggest that hepatocytes in the atrophying lobes do not progress beyond early G1 phase. In contrast, sustained activation of p53 beyond the early phase and late activation of c-Ha-ras followed by cyclin E/Cdk2 induction in the regenerating lobes drives hepatocytes to progress further towards late G1 phase and finally into $S$ phase of the cell cycle.

At 12 and 24 hours after PBL, no elevation in p53 mRNA over baseline levels was found in the atrophying lobes whereas the regenerating lobes showed a marked increase in p $53 \mathrm{mRNA}$
A

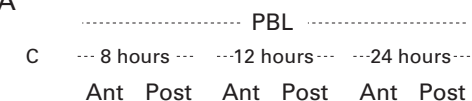

Ant Post Ant Post Ant Post

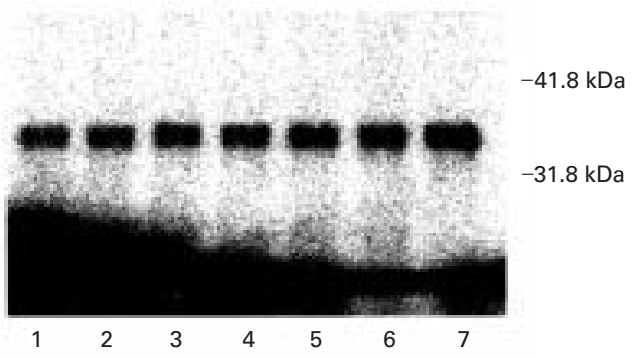

B

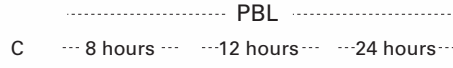

Ant Post Ant Post Ant Post

$-41.8 \mathrm{kDa}$

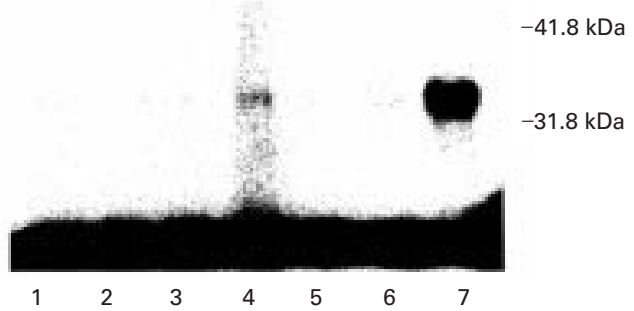

Figure 7 Cyclin dependent kinase (Cdk2) associated activity in cytoplasmic and nuclear fractions. Cdk2 protein was immunoprecipitated and a histone H1 kinase assay was performed followed by sodium dodecyl sulphate-polyacrylamide gel electrophoresis. (A) Low constitutive activity was detected in the cytosol of control livers $(C)$ and in the atrophying (Ant) and regenerating (Post) lobes after portal branch ligation (PBL) (lanes 2-7) which did not significantly vary during the experiment. (B) In contrast, no Cdk2 activity was observed in the nuclear fractions of control (C, lane 1) and PBL livers (lanes 2-6) until 24 hours. At 24 hours after PBL a sharp increase in Cdk2 activity was selectively found in the regenerating lobes (lane 7).

levels, peaking at 12 hours. Although an early non-specific rise in p53 protein was noted in both lobes five hours after PBL, p53 protein expression did not increase further in the anterior lobes thereafter while highly significant upregulation of $\mathrm{p} 53$ expression was observed in the posterior lobes 30 hours after PBL. These results are in agreement with previous data showing p53 protein peaks at six and 30 hours after $\mathrm{PH} .{ }^{29}$ However, p53 mRNA and protein levels were not tightly coupled, suggesting post-transcriptional regulation of p53 expression. Taken together, our findings suggest a link between p53 and processes leading to cellular proliferation.

Although the precise role of $\mathrm{p} 53$ in the network of cellular regulation in normal liver is largely unknown, there is increasing evidence that p53 may be required for G1 phase progression, as suggested by upregulation of its mRNA in many cycling cells, including primary cultured hepatocytes. ${ }^{30-33}$ During the cell cycle in vitro, the abundance of p53 increases from $\mathrm{G} 1$ to $\mathrm{S}^{30}{ }^{33}$ and a shift of $\mathrm{p} 53$ protein into the nucleus is observed at the G1/S transition. ${ }^{34}$ In the regenerating liver, p53 expression is increased in terms of mRNA ${ }^{19356}$ and protein levels, peaking at six and 30 hours after $\mathrm{PH}^{.29}{ }^{37}$ 

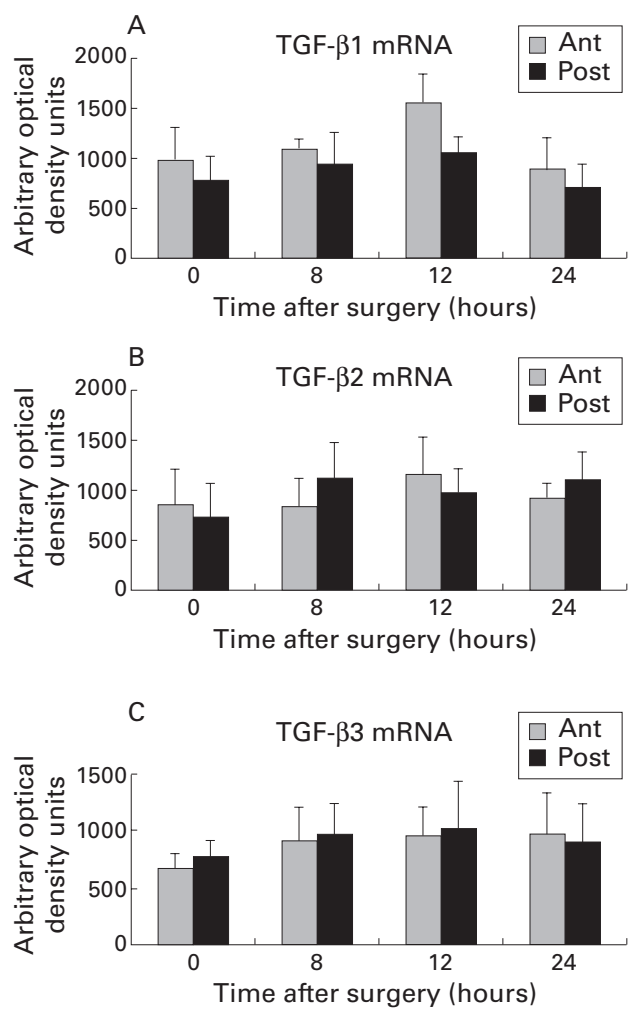

Figure 8 Quantification of transforming growth factor $(T G F)-\beta 1,-\beta 2$, and $-\beta 3 m R N A$ by densitometric analysis. Total liver RNA was subjected to reverse

transcription-polymerase chain reaction, as described in materials and methods using TGF- $\beta 1$ (A), TGF- $\beta 2$ (B), and $T G F-\beta 3(C)$ specific primers. The results were adjusted for their respective RPL19 levels and compared with a standard dilution curve obtained by amplification of liver $m R N A$ from lipopolysaccharide treated rats in the same polymerase chain reaction procedure. Compared with control levels (0 hours), no significant differences in TGF- $\beta$ $m R N A$ levels were noted at any of the investigated time points after portal branch ligation (eight, 12, or 24 hours).

The requirement of $\mathrm{p} 53$ for cell cycle progression in vivo is further supported by the observation that in ethanol fed rats, which show a strong reduction in hepatocyte replication and recovery of liver mass after $\mathrm{PH}$, no increase in p53 mRNA expression was found during late $\mathrm{G} 1$ despite activation of $\mathrm{TNF}-\alpha$, IL-6, and Stat $3 .^{38}$ In addition to its potential role in the regenerative phenomena, p53 has also been shown to inhibit cell division by blocking cell cycle progression in G1 phase. ${ }^{39-42}$ Therefore, it could act as a negative modulator of liver regeneration in the regenerating lobes, as indicated by its sustained activation ( 30 hours) beyond the peak of DNA synthesis ( 24 hours). Alternatively, p53 could contribute to cell cycle block in early G1 of the cells in the atrophying lobes. Nevertheless, absence of p53 activation in our study once the early nonspecific phase had been passed suggests that p53 may not be involved in the atrophic process of the anterior lobes.

Selective and progressive induction of c-Haras in the regenerating part of the liver from 12 hours onwards after PBL as well as upregulation of ras oncogenes after $\mathrm{PH}^{9}$ suggests a strong link between this proto-oncogene group and cellular proliferation. Ras acts as a transducer of the mitogenic signal and its function is required in G1 for passage through the restriction point of the cell cycle. ${ }^{43} 44 \mathrm{c}-\mathrm{Ha}$-ras may thus be one of the elements which contributes to the transformation of an initially non-specific cellular response into a specific one-that is, regeneration. However, the exact mechanisms through which ras proteins promote cell cycle progression remain unclear.

Progression through the cell cycle is governed by intermittent activation of cyclins and their associated kinase partners at key points of the cell cycle. ${ }^{11}$ There is growing evidence that the cyclin $\mathrm{E} / \mathrm{Cdk} 2$ complexes are the principal players contributing to the irreversibility of G1/S transition ${ }^{14}{ }^{45}$ and their presence and activation are required to pass this cell cycle checkpoint. ${ }^{28}{ }^{46}$ Our data on p53 and c-Ha-ras activation in the posterior lobes suggest that hepatocytes in the regenerating lobes progress to late G1 phase whereas those in the atrophying lobes are arrested in early-mid G1 phase. To further sustain this hypothesis and provide a potential link between p53/c-Ha-ras activation and the cell cycle, expression of cyclin $\mathrm{E}$ as well as expression and activity of its preferred kinase partner, Cdk2, were investigated in both parts of the liver. Cyclin E and Cdk2 were selectively upregulated in the cytoplasm of regenerating hepatocytes near the G1/S transition followed by transfer of cyclin $\mathrm{E}$ and $\mathrm{Cdk} 2$ into the nucleus. Activation of Cdk2 then takes place in the nucleus itself, as suggested by the selective and marked increase in Cdk2 associated kinase activity predominately in the nuclear fraction of the regenerating hepatocytes at 24 hours after surgery. Several recent studies have reported an increase in cyclin $\mathrm{E}$ and Cdk2 expression and activity close to the G1/S boundary after $\mathrm{PH}^{47} 48$ and a mechanism involving nuclear translocation and activation of Cdk2 has also been suggested. ${ }^{24}$ Interestingly, in our study, Cdk2 kinase activity was accompanied by the predominant appearance of the slower migrating cyclin $\mathrm{E}$ band of approximately $54 \mathrm{kDa}$ in the nuclear fraction on western blot analysis. A similar observation has recently been made by Albrecht and colleagues $^{48}$ in nuclear extracts from rats who underwent $\mathrm{PH}$. One explanation may be that the transition from inactive into active cyclin $\mathrm{E}$ is associated with changes in its phosphorylation status. It has been demonstrated that cyclin $\mathrm{E}$ undergoes phosphorylation changes near the G1/S transition in the cycling cell, including primary hepatocytes in culture. ${ }^{49}{ }^{50}$ Alternatively, the $54 \mathrm{kDa}$ form of cyclin $\mathrm{E}$ may represent the formerly reported longer splice variant of cyclin $\mathrm{E}^{27}$ and it is this variant which is mainly found and required in active cyclin E/Cdk2 complexes. Our observations emphasise the important role of cyclin E and Cdk2 in determining the commitment of the cell to undergo proliferation. The requirement of cyclin $\mathrm{E} / \mathrm{Cdk} 2$ in processes leading finally to cellular proliferation and subsequently liver regeneration is further supported by observations in 2-AAF treated rats or in $\mathrm{C} / \mathrm{EBP}$ beta knockout mice where lack of cyclin $\mathrm{E}$ expression at the G1/S phase restriction point is associated with 


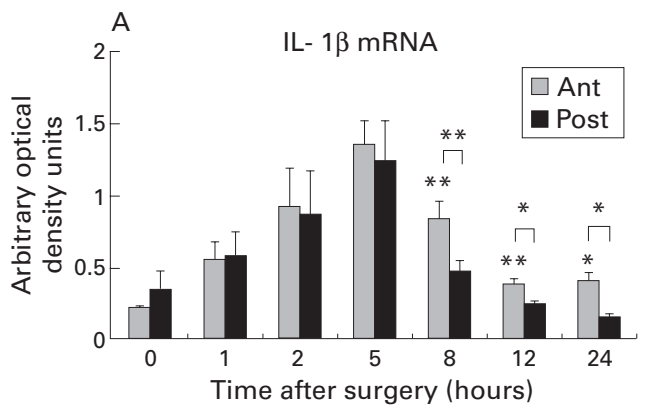

B

-..--. Dilutions -...-. - Control- -1 hour- -2 hours- -5 hours- -8 hours- -12 hours- -24 hours$1 / 2$ 1/4 1/10 1/20 Ant Post Ant Post Ant Post Ant Post Ant Post Ant Post Ant Post
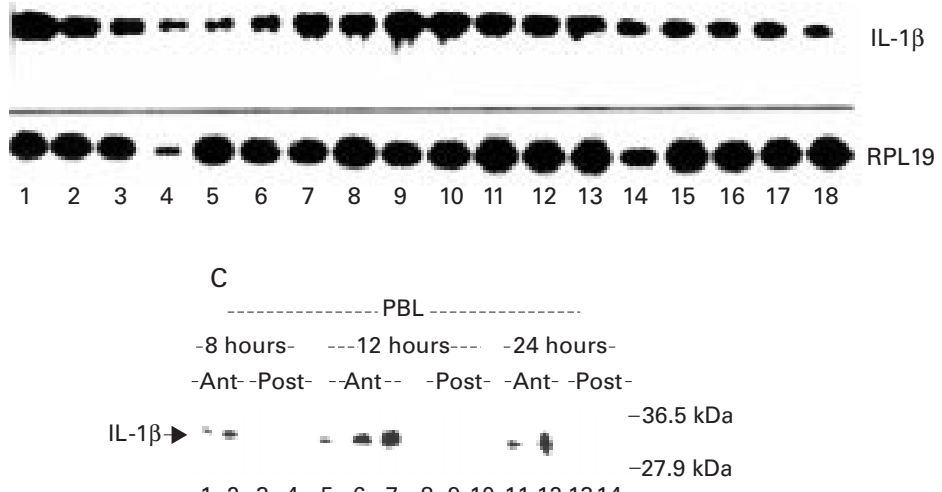

$\begin{array}{lllllllllllll}1 & 2 & 3 & 4 & 5 & 6 & 7 & 8 & 9 & 10 & 11 & 121314\end{array}$

Figure 9 Expression of interleukin (IL)-1 $\beta$ in atrophying and regenerating lobes after portal branch ligation (PBL). (A) Quantification of IL-1 $1 \beta$ mRA by densitometric analysis. IL-1 $\beta$ mRNA was significantly induced in both lobes during the first hours (1-5) after PBL. From eight hours after PBL, IL-1 $\beta$ mRNA returned to control levels in the regenerating lobes (Post) whereas significant activation of IL-1 persisted in the atrophying lobes $($ Ant $)\left({ }^{\star} p<0.05,{ }^{*} p<0.01\right)$. (B) Reverse transcription-polymerase chain reaction

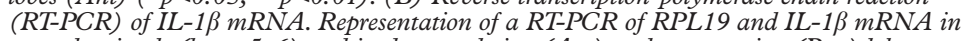
control animals (lanes 5-6) and in the atrophying (Ant) and regenerating (Post) lobes at various time points after portal branch ligation (lanes 7-18). Total liver RNA was subjected to RT-PCR, as described in materials and methods. The results were adjusted for their respective RPL19 levels and compared with a standard dilution curve obtained by amplification of liver $m R N A$ from lipopolysaccharide treated rats in the same PCR

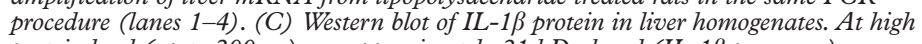
protein load (up to $300 \mu \mathrm{g}$ ), an approximately $31 \mathrm{kDa}$ band (IL-1 $\beta$ precursor) was observed in the atrophying lobes at eight (lanes 1, 2), 12 (lanes 5-7), and 24 hours (lanes $11,12)$ after $P B L$. No signal was detected in the proliferating lobes at the same time points (lanes 3, 4, 8-10, 13, 14, respectively).

disturbed liver regeneration after $\mathrm{PH}^{51}{ }^{52}$ In addition, our data provide a potential link between ras induction and activation of cyclin $\mathrm{E} / \mathrm{Cdk} 2$ which are selectively seen in the regenerating lobes. Interestingly, peak expression of both is seen 24 hours after PBL which correlates with peak DNA synthesis in this model of liver regeneration. ${ }^{73}$ Ras activity is required for phosphorylation of $\mathrm{pRb}$ in response to mitogenic signalling. ${ }^{54} 55$ Enforced $\mathrm{pRb}$ phosphorylation may be achieved, at least in part, by ras induced derepression and/or enhancement of cyclin E/Cdk2 activity. ${ }^{56}$ However, it has not yet been clearly established if ras directly targets cyclin $\mathrm{E} / \mathrm{Cdk} 2$ complexes or if indirect mechanisms are mainly involved, such as degradation of cyclin/Cdk inhibitory proteins and/or induction of other cyclins sequestering free cyclin/Cdk inhibitory proteins. ${ }^{145758}$

Hepatocytes as well as non-parenchymal cells can express TGF- $\beta^{185960}$ and TGF- $\beta$ has been shown to inhibit hepatocyte proliferation in vivo and in vitro. ${ }^{17}{ }^{61-63}$ It has been reported that TGF- $\beta$ exerts its inhibitory effect in the late G1 phase of the cell cycle near the G1/S boundary and may be involved in blocking cyclin E expression in hepatocytes. ${ }^{64}{ }^{65} \mathrm{We}$ therefore examined expression of TGF- $\beta$ mRNA and protein expression in both lobes, in particular during mid-late G1 phase (8-24 hours). No increase in TGF- $\beta$ mRNA or TGF- $\beta$ protein levels was noticed between eight and 24 hours after PBL in any part of the liver. Therefore, our results do not suggest a role for TGF- $\beta$ as a negative regulator of hepatocyte proliferation, at least during this critical period after PBL. Consequently, mechanisms other than TGF- $\beta$ seem to be important in regulating hepatocyte proliferation in vivo before the first wave of DNA synthesis. Nevertheless, TGF- $\beta$ may interfere to some extent with repression of hepatocyte proliferation or the final adjustment of liver size after the major wave of cell growth as peak TGF- $\beta$ induction has been reported after 24 hours following $\mathrm{PH}$ or $\mathrm{CCl}_{4}$ administration, time points which have not been assessed in our studies. ${ }^{17} 1866$

Given the low probability of TGF- $\beta$ being a major inhibitor of hepatocyte cell cycle progression in late G1, we assessed expression of IL-1, a negative regulator of hepatocyte proliferation in vitro, ${ }^{67} 68$ in both parts of the liver after PBL. During the last years, a potential suppressor effect of IL-1 on hepatocyte proliferation in vivo has also been suggested based on studies examining IL-1 expression after PH and in Kupffer cell depleted rats subjected to PH. ${ }^{16}{ }^{19}$ In addition, administration of an IL-1 receptor antagonist prior to $\mathrm{PH}$ resulted in a marked increase in hepatocyte proliferation in these animals. ${ }^{69}$ In our studies, IL- $1 \alpha$ levels did not change in any of the lobes during the first 24 hours after PBL hence excluding a major role of this cytokine in regulating liver cell proliferation. However, and interestingly, IL-1 $\beta$ expression showed sustained activation in the atrophying lobes from eight hours onwards after PBL whereas in the regenerating lobes IL-1 $\beta$ returned to control levels. This persistent activation of IL- $1 \beta$ in the atrophying part of the liver constitutes a further argument for IL-1 $\beta$ being involved in downregulation of cell cycle progression in the liver. However, the mechanisms by which IL- $1 \beta$ influences the cell cycle are still unknown. Nevertheless, although IL-1 $\beta$ was downregulated in the regenerating lobes between eight and 24 hours after PBL, we cannot exclude a regulatory influence of this cytokine at later time points.

In conclusion, the present results show that the cellular response, initially similar in the atrophying and regenerating lobes, follows a divergent specific pathway from 12 hours onwards after PBL. Our findings underline the importance of events occurring between eight and 12 hours (mid G1 phase) to determine the final outcome-that is, atrophy or proliferation - of each hepatocyte. p53, c-Haras, cyclin E, and Cdk2 seem to drive the commitment of cells to proliferate. IL-1 $\beta$ but not TGF- $\beta$ is associated with cellular atrophy and could play a role as a negative regulatory factor 
of hepatocellular proliferation in the atrophying lobes at a critical point in mid G1 phase of the cell cycle.

We thank Pascale Lause and Johan Wary for expert technical assistance. This work was supported by a grant from Glaxo-Wellcome, Belgium and a grant (3-4598-98) from the FRSM, Belgium.

1 Fausto N, Mead JE. Biology of disease. Regulation of liver growth: Protooncogenes and transforming growth factors. Lab Invest 1989;60:4-13.

2 Taub R. Transcriptional control of liver regeneration. FASEB F 1996;10:413-27.

3 Simpson KJ, Lukacs NW, Colletti L, et al. Cytokines and the liver. F Hepatol 1997;27:1120-32.

4 Fausto N, Laird AD, Webber EM. Role of growth factors and cytokines in hepatic regeneration. FASEB f 1995;9: 1527-36.

5 Michalopoulos GK, DeFrances MC. Liver regeneration. Science 1997;276:60-6.

6 Lambotte L, Saliez A, Triest S, et al. Control of rate and extent of the proliferative response after partial hepatectomy. Am $\mathcal{F}$ Physiol 1997;273:G905-12.

7 Stärkel P, Horsmans Y, Sempoux C, et al. After portal Stärkel $P$, Horsmans $\mathrm{Y}$, Sempoux $\mathrm{C}$, et al. After portal
branch ligation in rat, nuclear factor $\mathrm{\kappa B}$, interleukin- 6 , sigbranch ligation in rat, nuclear factor $\kappa \mathrm{B}$, interleukin-6, signal transducers and activators $3, \mathrm{c}-\mathrm{fos}, \mathrm{c}-\mathrm{myc}$, and c-jun are
similarly induced in the ligated and nonligated lobes. Hepa-

tology 1999;29:1463-70.
8 Lambotte L, Li B, Leclercq I, et al. The compensatory hyperplasia (liver regeneration) following ligation of a portal branch is initiated before atrophy of the deprived lobes. f Hepatol 2000;32:940-5.

9 Thompson NL, Mead JE, Braun L, et al. Sequentia protooncogene expression during rat liver regeneration. Cancer Res 1986;46:3111-17.

10 Bellamy COC, Clarke AR, Wyllie AH, et al. p53 deficiency in liver reduces local control of survival and proliferation, but does not affect apoptosis after DNA damage. FASEB $\mathcal{F}$ 1997;11:591-9.

11 Sherr CJ. Mammalian G1 cyclins. Cell 1993;73:1059-65.

12 Knoblich JA, Sauer K, Jones L, et al. S phase progression and its down-regulation during Drosophila embryogenesis and is required for the arrest of cell proliferation. Cell 1994; and is requirec

13 Duronio RJ, Brook A, Dyson N, et al. E2F-induced S-phase entry requires cyclin E. Genes Dev 1996;10:2505-13.

14 Sherr CJ, Roberts JM. CDK inhibitors: positive and negative regulators of G1-phase progression. Genes Dev 1999;13:1501-12.

15 Rai RM, Loffreda S, Karp CL, et al. Kupffer cell depletion abolishes induction of interleukin-10 and permits sustained overexpression of tumor necrosis factor alpha messenger RNA in the regenerating rat liver. Hepatology 1997;25:88995.

16 Boulton RA, Alison MR, Golding M, et al. Augmentation of the early phase of liver regeneration after $70 \%$ partial hepatectomy in rats following selective Kupffer cell depletion. $\mathcal{F}$ Hepatol 1998;29:271-80.

17 Braun L, Mead JE, Panzica M, et al. Transforming growth factor $\beta$ mRNA increases during liver regeneration: A possible paracrine mechanism of growth regulation. Proc Nat Acad Sci USA 1988;85:1539-43.

18 Bissell DM, Wang SS, Jarnagin WR, et al. Cell-specific expression of transforming growth factor- $\beta$ in rat liver. Evidence for autocrine regulation of hepatocyte proliferation. $f$ Clin Invest 1995;96:447-55.

19 Boulton R, Woodman A, Calnan D, et al. Nonparenchymal cells from regenerating rat liver generate interleukin- $1 \alpha$ and $-1 \beta$ : A mechanism of negative regulation of hepatocyte proliferation. Hepatology 1997;26:49-58.

20 Hattori M, Tugores A, Veloz L, et al. A simplified method for the preparation of transcriptionally active liver nuclear extracts. DNA Cell Biol 1990;9:777-81.

21 Chirgwin JM, Przybla AE, MacDonald RJ, et al. Isolation of biologically active ribonucleic acid from sources enriched in ribonucleases. Biochemistry 1977;18:5294-9.

22 Wahl GM, Stern M, Stark GR. Efficient transfer of large DNA fragments from agarose gels to diabenzyloxymethyl paper and rapid hybridization by using dextran sulfate. Proc Natl Acad Sci USA 1974;76:3683-8.

23 Soussi T, Caron de Fromentel C, Breugnot C, et al. Nucleotide sequence of a cDNA encoding the rat p53 nuclear oncoprotein. Nucleic Acids Res 1988;16:11384

24 Jaumot M, Estanyol JM, Serratosa J, et al. Activation of $\mathrm{Cdk} 4$ and Cdk2 during rat liver regeneration is associated with intranuclear rearrangements of cyclin-Cdk complexes. Hepatology 1999;29:385-95.

25 Horsmans Y, Stevens M, Geubel A, et al. Immunoquantification of cytochrome P-450 3A on rat paraffin-embedded liver tissue. Liver 1992;12:344-50.

26 Shi SR, Key ME, Kalra KL. Antigen retrieval in formalin-fixed paraffin embedded tissues: an enhancement method for immunohistochemical staining based on microwave oven heating of tissue sections. F Histochem microwave oven heating
Cytochem 1991;39:741-8.

27 Sewing A, Ronicke V, Burger C, et al. Alternative splicing of human cyclin E. F Cell Sci 1994;107:581-8.
28 Ohtsubo M, Theodoras AM, Schumacher J, et al. Human cyclin $\mathrm{E}$, a nuclear protein essential for the G1-to-S phase cyclin E, a nuclear protein essential for the
transition. Mol Cell Biol 1995;15:2612-24.

29 Fan G, Xu R, Wessendorf MW, et al. Modulation of retinoblastoma-related proteins in regenerating rat liver and primary hepatocytes. Cell Growth Differ 1995;6:146376

30 Danova M, Giordano M, Mazzini G, et al. Expression of 53 during the cell cycle measured by flow cytometry in human leukemia. Leuk Res 1990;14:417-22.

31 Mosner J, Deppert W. p53 and $\mathrm{mdm} 2$ are expressed independently during cellular proliferation. Oncogene 1994; 9:3321-8.

32 Deppert W, Buschhausen-Denker G, Patschinsky T, et al. Cell cycle control of p53 in normal (3T3) and chemically transformed (MethA) mouse cells: II Requirement for cell cycle progression. Oncogene 1990;5:1701-6.

33 Sugiyama A, Nagaki M, Shidoji Y, et al. Regulation of cell cycle-related genes in rat hepatocytes by transforming cycle-related genes in rat hepatocytes by transforming
growth factor $\beta 1$. Biochem Biophys Res Com 1997;238:53943.

34 Shaulsky G, Ben-Ze'ev A, Rotter V. Subcellular distribution of p53 protein during the cell cycle of Balb/c 3T3 cells. Oncogene 1990;5:1707-11.

35 Biesada E, Chorazy M. Expression of cell-cycle dependent genes in regenerating rat liver. Cell Biol Int Rep 1988;12: 483-92.

36 Fausto N, Mead JE. Role of protooncogenes and transforming growth factors in normal and neoplastic liver growth. Prog Liver Dis 1990;9:57-71.

37 Kren BT, Trembley JH, Steer CJ. Alteration in mRNA stability during rat liver regeneration. Am f Physiol 1996;270 G763-77.

38 Yang SQ, Lin HZ, Yin M, et al. Effects of chronic ethanol consumption on cytokine regulation of liver regeneration. Am f Physiol 1998;275:G696-704.

39 Polyak K, Waldman T, He TC, et al. Genetic determinants of $\mathrm{p} 53$-induced apoptosis and growth arrest. Genes Dev 1996;10:1945-52.

40 Attardi LD, Lowe SW, Brugarolas J, et al. Transcriptional activation by $\mathrm{p} 53$, but not induction of the p 21 gene, is essential for oncogene-mediated apoptosis. EMBO $\mathcal{F} 1996$; 15:3693-701.

41 Baker SJ, Markowitz S, Fearon ER, et al. Suppression of human colorectal carcinoma cell growth by wild-type p53. Science 1990;249:912-15.

42 Mercer WE, Avignolo C, Baserga R. Role of the p53 protein in cell proliferation as studied by microinjection of monoclonal antibodies. Mol Cell Biol 1984;4:276-81.

43 Pronk GJ, Bos JL. The role of p21ras in receptor tyrosine kinase signaling. Biochem Biophys Acta 1994;1198:131-47.

44 Dobrowolski S, Harter M, Stacey DW. Cellular ras activity is required for passage through multiple points of the G0/G1 required for passage through multiple points of the G0/G1

45 Connell-Crowley L, Elledge SJ, Harper JW. G1 cyclindependent kinases are sufficient to initiate DNA synthesis in quiescent human fibroblasts. Curr Biol 1998;8:65-8.

46 Tsai LH, Lees E, Faha B, et al. The cdk2 kinase is required for the G1-to-S transition in mammalian cells. Oncogene 1993;8:1593-602.

47 Ehrenfried JA, Tien CK, Thompson EA, et al. Cell cycle-mediated regulation of hepatic regeneration. Surgery 1997;122:927-35.

48 Albrecht JH, Brenda MR, Nelsen CJ, et al. Regulation of G1 cyclin-dependent kinases in the liver: role of nuclear locali-
zation and p27 sequestration. Am $\mathcal{F}$ Physiol 1999;277: G1207-16.

49 Koff A, Cross F, Fisher A, et al. Human cyclin E, a new cyclin that interacts with two members of the CDC2 gene family. Cell 1991;66:1217-28.

50 McIntyre M, Desdouets C, Senamaud-Beaufort C, et al. Differential expression of the cyclin-dependent kinase inhibitor p27 in primary hepatocytes in early-mid G1 and G1/S transitions. Oncogene 1999;18:4577-85.

51 Trautwein C, Will M, Kubicka S, et al. 2-acetaminofluorene blocks cell cycle progression after hepatectomy by p21 induction and lack of cyclin E expression. Oncogene 1999;18:6443-53.

52 Greenbaum LE, Wei L, Cressman DE, et al. CCAAT enhancer-binding protein $\beta$ is required for normal hepatocyte proliferation in mice after partial hepatectomy. F Clin Invest 1998;102:996-1007.

53 Rozga J, Jeppsson B, Bengmark S. Portal branch ligation in the rat. Reevaluation of a model. Am $\mathcal{F}$ Pathol 1986;125: $300-8$

54 Mittnacht S, Paterson H, Olson MF, et al. Ras signaling is required for inactivation of the tumor suppressor $\mathrm{pRb}$ cellcycle control protein. Curr Biol 1997;7:219-21.

55 Peeper DS, Upton TM, Ladha MH, et al. Ras signaling linked to the cell-cycle machinery by the retinoblastoma protein. Nature 1997;386:177-81.

56 Leone G, DeGregori J, Sears R, et al. Myc and Ras collaboate in inducing accumulation of active cyclin $\mathrm{E} / \mathrm{Cdk} 2$ and E2F. Nature 1997;387:422-6.

57 Aktas H, Cai H, Cooper GM. Ras links growth factor signaling to the cell cycle machinery via regulation of cyclin D1 and the Cdk inhibitor p27KIP1. Mol Cell Biol 1997;17: 3850-7.

58 Kawada M, Yamagoe S, Murakami Y, et al. Induction of p27Kip1 degradation and anchorage independence by Ras through the MAP kinase signaling pathway. Oncogene 1997; 15:629-37.

59 Jakowlev SB, Mead JE, Danielpour D, et al. Transforming growth factor- $\beta$ (TGF- $\beta$ ) isoforms in rat liver regeneration: 
messenger RNA expression and activation of latent TGF- $\beta$. Cell Regul 1991;2:535-48.

60 Chunfang G, Gressner G, Zoremba M, a growth factor $\beta$ (TGF- $\beta$ ) expression in isolated and cultured rat hepatocytes. F Cell Physiol 1996;167:394-405.

61 Nakamura T, Tomita Y, Hirai R, et al. Inhibitory effect of transforming growth factor- $\beta$ on DNA synthesis of adult rat hepatocytes in primary culture. Biochem Biophys Res Commun 1985;133:1042-50

62 Strain AJ, Frazer A, Hill DJ, et al. TGF $\beta$ inhibits DNA synthesis in hepatocytes isolated from normal and regenerating rat liver. Biochem Biophys Res Commun 1987;145:43642 .

63 Russell WE, Coffey RJ, Ouellette AJ, et al. Type $\beta$ transforming growth factor reversibly inhibits the early proliferative response to partial hepatectomy in the rat. Proc Natl Acad Sci USA 1988;85:5126-30.

64 Attisano L, Wrana JL, Lopez-Casillas F, et al. TGF- $\beta$ receptors and actions. Biochim Biophys Acta 1994;1222:71-80.
65 Thoresen $\mathrm{GH}$, Refnes $\mathrm{M}$, Christoffersen $\mathrm{T}$. Inhibition of hepatocyte DNA synthesis by transforming growth factor $\beta 1$ and cyclic AMP: Effect immediately before the G1/S border. Cancer Res 1992;52:3598-603.

66 Masataka D, Matsuzaki K, Matsushita M, et al. Differential expression of transforming growth factor- $\beta$ and its receptors in hepatocytes and nonparenchymal cells of rat liver after $\mathrm{CCl}_{4}$ administration. F Hepatol 1998;28:572-81.

67 Nakamura T, Arakaki R, Ichihara A. Interleukin-1 $\beta$ is a potent growth inhibitor of adult rat hepatocytes in primary culture. Exp Cell Res 1988;179:488-97.

68 Beyer HS, Theologides A. Tumor necrosis factor- $\alpha$ is a direct hepatocyte mitogen in the rat. Biochem Mol Biol Int 1993;29:1-4.

69 Boermeester MA, Straatsburg IH, Houdijk APJ, et al. Endotoxin and interleukin-1 related hepatic inflammatory response promotes liver failure after partial hepatectomy. Hepatology 1995;22:1499-506. 